\title{
THE EFFECT OF RECTUS SHEATH BLOCK AS A SUPPLEMENT OF GENERAL ANESTHESIA ON POSTOPERATIVE ANALGESIA IN ADULT PATIENT UNDERGOING UMBILICAL HERNIA REPAIR
}

\author{
Andrijan Kartalov ${ }^{1}$, Nikola Jankulovski ${ }^{3}$, Biljana Kuzmanovska ${ }^{1}$, Milka Zdravkovska ${ }^{2}$, \\ Mirjana Shosholcheva ${ }^{5}$, Marija Tolevska ${ }^{1}$, Filip Naumovski ${ }^{1}$, Marija Srceva ${ }^{1}$, \\ Aleksandra Panovska Petrusheva ${ }^{1}$, Rexhep Selmani ${ }^{3}$, Atanas Sivevski ${ }^{4}$ \\ ${ }^{1}$ Clinic for Anesthesiology, Reanimatology and Intensive Care Unit - KARIL, Skopje, Republic of Macedonia \\ ${ }^{2}$ Faculty of Medical Sciences, “Goce Delchev University”, Shtip, Republic of Macedonia \\ ${ }^{3}$ Clinic for Abdominal surgery, Skopje, Republic of Macedonia \\ ${ }^{4}$ University Clinic for Genecology and Obstetric, Skopje, Republic of Macedonia
}

Corresponding author: Andrijan Kartalov, MD, Phd, Clinic for Anesthesia, Reanimation and Intensive Care, Faculty of Medicine, University St. "Cyril and Methodius" - Skopje, Tel: 38976606 803; e-mail: andrijankartalov@gmail.com

\section{ABSTRACT}

Background: Ultrasound guided rectus sheath block can block the ventral rami of the 7th to 12th thoracolumbar nerves by injection of local anesthetic into the space between the rectus muscle and posterior rectus sheath. The aim of this randomized double-blind study was to evaluate the analgesic effect of the bilateral ultrasound guided rectus sheath block as supplement of general anesthesia on patents undergoing elective umbilical hernia repair.

Methods: After the hospital ethics committee approval, 60 (ASA I-II) adult patients scheduled for umbilical hernia repair were included in this study. The group I $(n=30)$ patents received only general anesthesia. In the group II $(\mathrm{n}=30)$ patents after induction of general anesthesia received a bilateral ultrasound guided rectus sheath block with $40 \mathrm{ml}$ of $0.25 \%$ bupivacaine. In this study we assessed demographic and clinical characteristics, pain score - VAS at rest at 2, 4, 6, 12 and 24 hours after operation and total analge $\neg$ sic consumption of morphine dose over 24-hours.

Results: There were statistically significant differences in VAS scores between the groups I and II at all postoperative time points $-2 \mathrm{hr}, 4 \mathrm{hr}, 6 \mathrm{hr}, 12 \mathrm{hr}$ and $24 \mathrm{hr}$. ( $(\mathrm{P}<0.00001)$. The cumulative 24 hours morphine consumption after the operation was significantly lower in the group II (mean $=3.73 \pm 1.41)$ than the group I $($ mean $=8.76 \pm 2.41)$. This difference was statistically significant $(\mathrm{p}=0.00076)$.

Conclusion: The ultrasound guided rectus sheath block used for umbilical hernia repair could reduce postoperative pain scores and the amount of morphine consumption in 24 hours postoperative period.

Keywords: Umbilical hernia repair, Ultrasound guided rectus sheath block, Bupivacaine

\section{INTRODUCTION}

Recent clinical trials showed that ultrasound guided regional anesthesia techniques for abdominal wall can be effective components of multimodal postoperative analgesia with limited side-effects, haemodynamic effects and perioperative reduction in the use of morphine. [1,2]
The rectus sheath block was first described by Schleich in 1899 and it was initially used for abdominal wall muscle relaxation and analgesia during midline laparotomy by blocking the terminal branches of the thoracolumbar nerves. [4, 5] Like other central non-neuraxial regional anesthesia technique, rectus sheath block is not useful for 
analgesia of the abdominal viscera. [6] Rectus sheath block provides only somatic analgesia for abdominal wall vertical midline (or paramedian) surgical incisions from the xiphoid process superiorly to the symphysis pubis inferiorly. Rectus sheath block is indicated for single incision at laparoscopic surgery, other types of peri-umbilical incisions, umbilical and paraumbilical hernia repair in adults and children, gynaecological procedures with Pfannenstiel incision, abdominoplasty and open radical cystectomy. [7-13]

The aim of this ultrasound regional anesthesia technique is to block the ventral rami of the 7 th to 12 th thoracolumbar nerves by injection of local anesthetic into the space between the rectus muscle and posterior rectus sheath which results in anesthesia of the periumbilical area (spinal dermatomes 9,10 , and 11). It is a rather specific, limited region of blockade, hence its specific indications. The thoracolumbar nerves $7^{\text {th }}$ to 12th course along the anterolateral wall within the transversus abdominis plane, and continue anteromedially within the transversus abdominis plane. [14] The nerves then enter the lateral aspect of rectus abdominal muscules and contribute to the formation of a nerve plexus that runs craniocaudally within the muscle in close relation to the lateral branch of the deep epigastric artery. [15] The nerves provide both muscular and cutaneous branches to innervate the muscle fibers and overlying skin.

The ultrasound procedure is performed with ultrasound high frequency $(5-13 \mathrm{MHz})$ probe which is placed immediately laterally to the umbilicus. The needle is inserted in-plane in a medial to lateral orientation, through the subcutaneous tissue, to pierce through the anterior rectus sheath. The needle is further advanced through the body of the muscle until the tip rests on the posterior rectus sheath. After negative aspiration, 1 to $2 \mathrm{~mL}$ of local anesthetic is injected to verify needle tip location. The distribution of the local anesthetic can be monitored under real-time imaging. The local anesthetic is injected between the RAM and the posterior sheath.

In an adult patient, $40 \mathrm{~mL}$ of local anesthetic (e.g., $0.25 \%$ bupivacaine) per side (supraumbilical and infraumbilical point) is usually sufficient for successful blockade. Skin incision can be performed 15 minutes or later after placement of the block.

The aim of this randomized controlled double-blind study was to evaluate the analgetic effect and postoperative morphine consumption of the single pre-incision bilateral ultrasound guided rectus sheath block as supplement to general anesthesia on adult patients undergoing umbilical hernia repair.

\section{MATERIALS AND METHODS}

After the hospital ethics committee approval, 60 American Society of Anesthesiologists (ASA) physical statuses I-II patients, aged between 18-75 years scheduled for open umbilical hernia repair were included in this clinical trial.

Exclusion criteria included age $<18$, ASA class III-IV, known allergy to paracetamol, chronic hepatic or renal failure, any contraindications to regional techniques (allergy to amino amide local anesthetics, infection around the site of the block, and coagulation disorder), history of analgesics dependence and patients with body mass index $(\mathrm{BMI})>35 \mathrm{~kg} / \mathrm{m}^{2}$. The study was performed between February 2016 and September 2016.

All patients for umbilical hernia repair were randomly divided in two groups, Group I $(n=30)$ the patients who received only general anesthesia and the group II $(\mathrm{n}=30)$ - the patients who received ultrasound guided bilateral rectus sheath block and general anesthesia.

The premedication was done with midazolam in dose of $0.02 \mathrm{mg} / \mathrm{kg}$ intravenous (IV) before surgery. Induction of general anesthesia to all 60 patients was performed with $2 \%$ propofol $-1-2$ $\mathrm{mg} / \mathrm{kg}$, lidocaine $40 \mathrm{mg}$, and fentanil $2-3 \mathrm{mcg} /$ $\mathrm{kg}$. After unconsciousness, rocuronium $0.6 \mathrm{mg} / \mathrm{kg}$ was injected and then endotracheal intubation was done following the 90 seconds mask ventilation. Pressure controlled ventilation was done by providing oxygen $50 \%$ and air $50 \%$ at the flow rate of $2 \mathrm{~L}$ per min. Maintaining the anesthesia was done by sevoflurane at $05-1 \mathrm{MAC}$. The blood pressure was regulated in the $20 \%$ range of the blood pressure measured when entering the operation room.

After the induction of general anesthesia, the rectus sheath block was performed with The Sonosite Nanomaxx Ultrasound Mashine with a 5-13 MHz linear probe.

Immediately laterally to the umbilicus at the booth side (supraumbilical and infraumbilical point), $40 \mathrm{ml}$ of $0.25 \%$ bupivacaine was injected between the rectus abdominis muscule and the posterior sheath under direct vision with a 
22G needle (Stimuplex D Plus 22G x 80mm, B. Braun, Melsungen,Germany). All patients were operated by the same surgeon. During surgery in 15 minute intervals, we monitoredthe following paramatresoperation time, heart rate, ECG, noninvasive blood pressure, periphery oxygen saturation, capnography and bispectral index (BIS). Before the end of the surgery all patients received $1 \mathrm{~g}$ of paracetamol intravenously.

The postoperative pain assessment for all patients was done in the recovery room and in the surgical ward by an anesthesiologist (independent observer) at 2, 4, 6, 12, and 24 hours after surgery. VAS (0: no pain to 10: worst imaginable pain) was used for pain assessment, for which all patients received instructions before the surgery. Standard postoperative analgesia consisted of paracetamol $1 \mathrm{gr}$ i.v. at every 6 hours. During the first postoperative day a rescue analgesic morphine IV $0.05 \mathrm{mg} / \mathrm{kg}$ was applied to patients if their VAS score was $>3$ and if paracetamol had been administered less than 6 hours before. Total
$N Y$ ). Data were expressed as mean \pm standard deviation. Kolmogorov Smirnov test and Shapiro-Wilk's W test were used to identify the distribution of variables. Nonparametric statistical methods were used for the heterogeneous variables. The Mann -Whitney U test was used for nonparametric variables. A P - value less than 0.05 was considered statistically significant.

\section{RESULTS}

Demographic variables and operative characteristics were similar between the groups. (Table 1) There were no statistically significant differences in age (years), sex (F/M), ASA (I/II), BMI (kg/ $\mathrm{m}^{2}$ ), operative time (minutes) and discharge time after the surgery between group I and II.

During the surgery, there were no statistically significant differences in mean blood pressure, heart rate and oxygen saturation among measurement times within both groups.

Table 1. Demographic and clinical characteristics

\begin{tabular}{|l|c|c|c|}
\hline \multicolumn{1}{|c|}{ Variable } & $\begin{array}{c}\text { Group I } \\
(\mathrm{n}=30)\end{array}$ & $\begin{array}{c}\text { Group II } \\
(\mathrm{n}=30)\end{array}$ & P-value \\
\hline Age, years & $42.4 \pm 14.7$ & $41.3 \pm 15.8$ & $\mathrm{p}=0.3905$ \\
\hline Sex (F/M), number & $4 / 26$ & $5 / 25$ & $\mathrm{p}=0.7136$ \\
\hline ASA (I/II), number & $16 / 14$ & $16 / 14$ & $\mathrm{p}=1.0$ \\
\hline BMI (kg/m2) & $24.9 \pm 4.4$ & $25.4 \pm 4.1$ & $\mathrm{p}=0.6505$ \\
\hline Operative time (minutes) & $45.6 \pm 10$ & $49.7 \pm 15$ & $\mathrm{p}=0.2179$ \\
\hline $\begin{array}{l}\text { Discharge one day after } \\
\text { surgery (\%) }\end{array}$ & $\mathrm{n}=30(100 \%)$ & $\mathrm{n}=30(100 \%)$ & $\mathrm{p}=1.0$ \\
\hline
\end{tabular}

analgesic consumption and morphine dose over the $24-h$ study period was documented. Rescue antiemetics were given to any patient complaining of nausea and vomiting.

Data analysis was performed by using Statistical Package for Social Sciences (SPSS) version 17.0 software (IBM Corporation, Armonk,
There were statisti $\neg$ cally significant differences in VAS scores between group I and group II at all postoperative time points $-2 \mathrm{hr}, 4 \mathrm{hr}, 6$ $\mathrm{hr}, 12 \mathrm{hr}$. and $24 \mathrm{hr} . \quad(\mathrm{p}<0.00001)$. VAS scores in group II are significantly lower (Table 2 and Figure 1). 
Table 2. VAS scores in group I and II at all postoperative time points

\begin{tabular}{|c|c|c|c|c|c|}
\hline & VAS $2 \mathrm{~h}$ & VAS $4 \mathrm{~h}$ & VAS $6 \mathrm{~h}$ & VAS $12 \mathrm{~h}$ & VAS $24 \mathrm{~h}$ \\
\hline Group 1 & $4 \pm 0.94$ & & & & \\
\hline Group 2 & $\begin{array}{l}1 \pm 0.0 \\
p<0.0001\end{array}$ & & & & \\
\hline Group 1 & & $4 \pm 0.69$ & & & \\
\hline Group 2 & & $\begin{array}{l}1 \pm 0.0 \\
p<0.0001\end{array}$ & & & \\
\hline Group 1 & & & $4 \pm 0.78$ & & \\
\hline Group 2 & & & $\begin{array}{l}2 \pm 0.69 \\
p<0.0001\end{array}$ & & \\
\hline Group 1 & & & & $4 \pm 0.66$ & \\
\hline Group 2 & & & & $\begin{array}{l}2 \pm 0.61 \\
p<0.0001\end{array}$ & \\
\hline Group 1 & & & & & $3 \pm 0.28$ \\
\hline Group 2 & & & & & $\begin{array}{l}1 \pm 0.0 \\
p<0.0001\end{array}$ \\
\hline
\end{tabular}

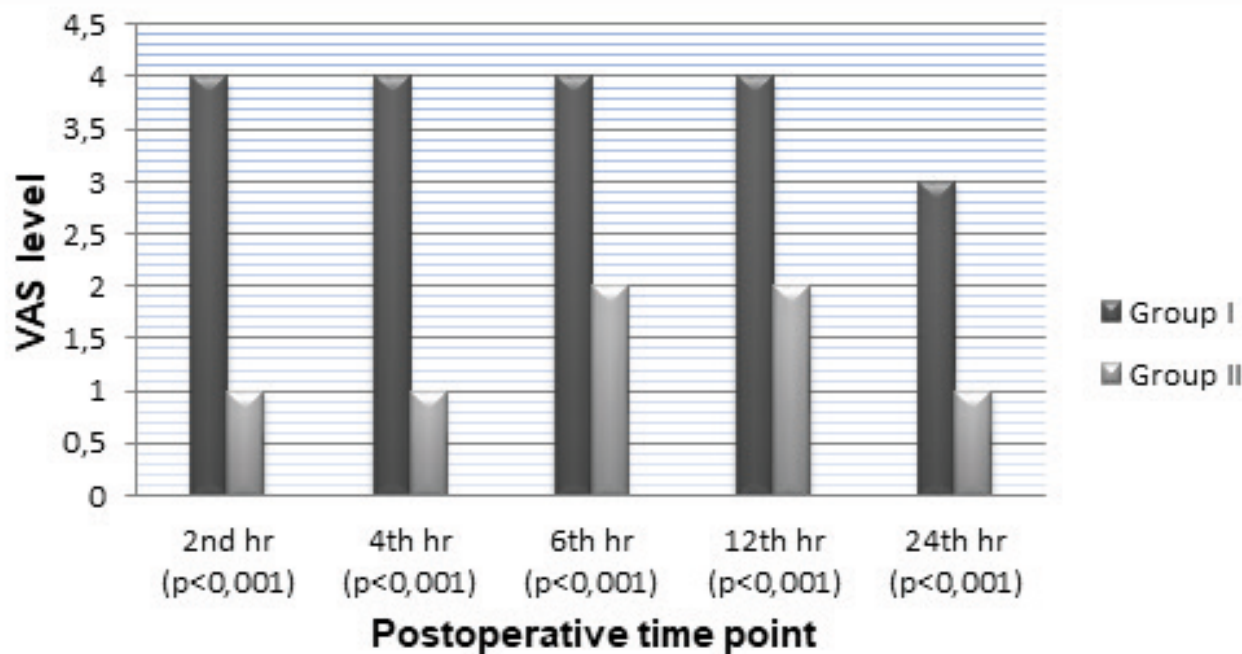

Figure 1. VAS scores in group I and II at all postoperative time points

The cumulative 24 hours morphine consumption after the operation (umbilical hernia repair) was significantly lower in the group of patients who underwent the ultrasound guided rectus sheath block after general anesthesia (group
II $-3.73 \pm 1.41)$ than the group of patients who underwent only general anesthesia (group I - 8.76 \pm 2.41 ). This difference was statistically significant (Mann -Whitney U test: $Z=3.365 ; \mathrm{p}=0$. 00076) (Figure 2). 


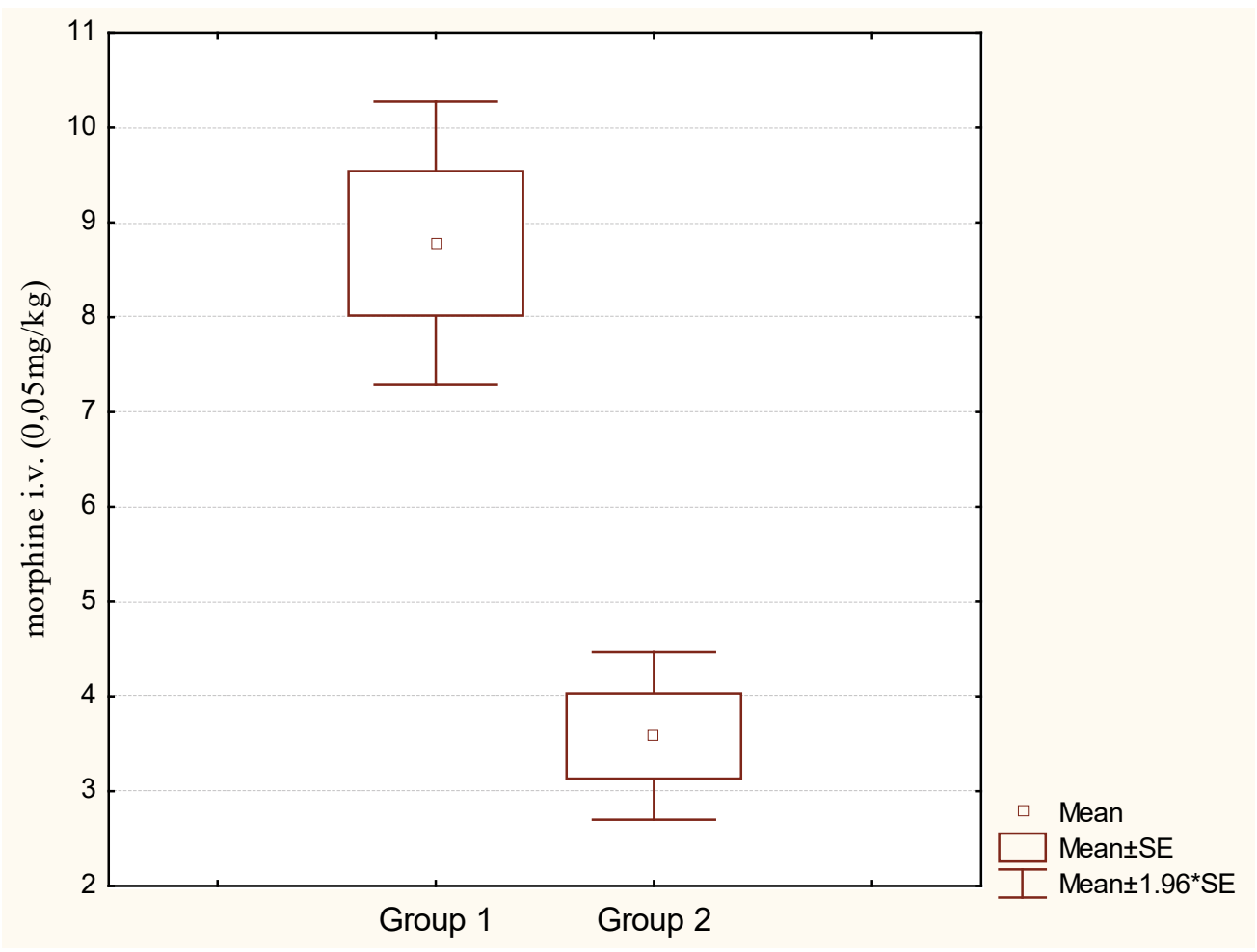

Figure 2. Cumulative 24 hours morphine consumption after the operation in group I and II

The patients were discharged one day after surgery, highly satisfied with the anesthetic choice. There were no major intra or postoperative complications related to rectus sheath block.

\section{DISCUSSION}

This study has demonstrated that for umbilical hernia repair, ultrasound guided rectus sheath block with general anesthesia provides more effective pain relief than general anesthesia alone. $\mathrm{Pa}$ tients in ultrasound guided rectus sheath block and general anesthesia group had better VAS scores with less morphine utilization in the first postoperative day and consequently, developed fewer side effects such as respiratory depression, excessive sedation, and postoperative nausea and vomiting. Our study has several limitations. First of all, the total dose of remifentanil used during the operation was not assessed. During the first postoperative day we did not assess pain on move $\neg$ ment and coughing, but we only assessed the pain at rest. The next limitation of our study is that we evaluate only a single-dose RSB because a continuous infusion catheter cannot be used due to the current technical level and higher cost. However, it could be attempted in the future studies.

Moreover, some patients who are morbidly obese or having obstructive sleep apnea will maximally benefit from the bilateral ultrasound guided rectus sheath block through the opioid-sparing effects. [16] Besides, bilateral ultrasound guided rectus sheath block also prevents the hemodynamic responses of surgical incision, so patients having ischemic heart disease or stenotic valvular lesion like mitral or aortic stenosis, where tachycardia is undesirable, will also benefit from pre incisional bilateral ultrasound guided rectus sheath block. This block may be a relatively safer alternative comparable to neuraxial block for perioperative analgesia in patients having coagulopathy. [16] Ultrasound guided regional analgesia techniques are now widely accepted to supplement multimodal analgesia strategies. [17]

Adding adjuvants to local anesthetic may improve efficacy and duration of the ultrasound guided rectus sheath block that can be tried in future studies. Studying the spread of local anesthetic and contrast solution into the Rectus sheath using magnetic resonance is recommended for 
future studies. This will help in appreciation of the spread pattern of local anesthetic in the posterior rectus sheath in different sites of injection as well as single and multiple injections. [18, 19]

The volume and concentration of local anesthetic solution used in ultrasound guided rectus sheath block in our study are compared to those in the literature, e.g., $20 \mathrm{ml} 0.25 \%$ bupivacaine on each side ( $40 \mathrm{ml}$ of $0.25 \%$ bupivacaine). [20] We did not want to exceed the maximum recommended dose for bupivacaine of $2 \mathrm{mg} / \mathrm{kg}$.

The rectus sheath block provides excellent analgesia for midline incisions around the umbilicus and laparoscopic surgery. It has been shown to provide better analgesia than intraperitoneal or intraincisional local anaesthetic infiltration in gynaecological surgery. [21, 22, 23] Moreover in children, ultrasound guided rectus sheath block provided superior analgesia compared with local anaesthetic infiltration of the surgical site for umbilical hernia repair. [24] The study of Godden at al. shows that the use of ultrasound guided rectus sheath block for postoperative analgesia following open colorectal surgery is as effective as epidural anesthesia with the potential benefits of a reduced incidence of hypotension. [25]

Potential adverse events of the ultrasound guided rectus sheath block include failed block, peritoneal injection of the local anesthetic, puncture of epigastric vessels and wound infections are rare and they have been described only after blind insertion using anatomic landmarks. [19] A haematom of the rectus sheath is of much less significance than that of the epidural space and, as a consequence, allows the use of ultrasound guided rectus sheath block when epidural catheters are contra-indicated owing to concomitant anticoagulation.

In conclusion, the ultrasound guided rectus sheath block is an effective and safe adjunct to multimodal postoperative analgesia. For umbilical hernia repair this technique when used with general anesthesia, was found effective in reducing a postoperative VAS score and opioid consumption compared to general anesthesia alone.

\section{REFERENCES}

1. Baig MK, Wexner SD. Postoperative ileus: a review. Dis Colon Rectum. 2004;47(4):516-26. doi: 10.1007/s10350-003-0067-9.

2. Cowlishaw PJ, Scott DM, Barrington MJ. The role of regional anaesthesia techniques in the management of acute pain. Anaesth Intensive Care. 2012; 40(1):33-45.

3. Sites BD, Brull R. Ultrasound guidance in peripheral regional anesthesia: philosophy, evidence-based medicine, and techniques. Curr Opin Anaesthesiol. 2006;19 (6):630-9. doi: 10.1097/ ACO.0b013e3280101423.

4. Schleich CL. Schmerzlose operationen. 4th Ed. Berlin: Springer, 1899; 240-8.

5. Yentis SM, Hills-Wright P, Potparic O. Development and evaluation of combined rectus sheath and ilioinguinal blocks for abdominal gynaecological surgery. Anaesthesia. 1999; 54(5):475-9.

6. Sviggum HP, Niesen AD, Sites BD, Dilger JA. Trunk blocks 101: transversus abdominis plane, ilioinguinal-iliohypogastric, and rectus sheath blocks. Int Anesthesiol Clin. 2012; 50(1):74-92. Doi:

7. Gurnaney HG, Maxwell LG, Kraemer FW, et al. Prospective randomized observer-blinded study comparing the analgesic efficacy of ultrasound-guided rectus sheath block and local anaesthetic infiltration for umbilical hernia repair. $\mathrm{Br} \mathrm{J}$ Anaesth 2011; 107:790-795.

8. 8. Azemati S, Khosravi MB. An assessment of the value of rectus sheath block for postlaparoscopic pain in gynecological surgery. J Minim Invasive Gynecol 2005; 12:12-15.

9. Shido A, Imamachi N, Doi K, et al. Continuous local anesthetic infusion through ultrasound-guided rectus sheath catheters. Can J Anesth 2010; 57:1046-1047.

10. Malchow R, Jaeger L, Lam H. Rectus sheath catheters for continuous analgesia after laparotomy-without postoperative opioid use. Pain Med 2011; 12:1124-1129.

11. Breschan C, Jost R, Stettner H, et al. Ultrasound-guided rectus sheath block for pyloromy- 
otomy in infants: a retrospective analysis of a case series. Paediatr Anaesth 2013;23:1199-1204.

12. Godden AR, Marshall MJ, Grice AS, et al. Ultrasonography guided rectus sheath catheters versus epidural analgesia for open colorectal cancer surgery in a single centre. Ann R Coll Engl 2013; 95:591-594.

13. Dutton TJ, McGrath JS, Daugherty MO. Use of rectus sheath catheters for pain relief in patients undergoing major pelvic urological surgery. BJU Int. 2014; 113; 246-253.

14. Rozen WM, Tran TMN, Ashton MW, et al. Refining the course of the thoracolumbar nerves: a new understanding of the innervation of the anterior abdominal wall. Clin Anat 2008; 21:325-333.

15. Rozen WM, Ashton MW, Murray ACA, Taylor GI. Avoiding denervation of rectus abdominis in the DIEP flap harvest: the importance of medial row perforators. Plast Reconstr Surg 2008; 122:710-716.

16. Khaled Abdelsalam, OW Mohamdin . Ultrasound-guided rectus sheath and transversus abdominis plane blocks for perioperative analgesia in upper abdominal surgery: A randomized controlled study. Saudi J Anaesth. 2016 Jan-Mar; 10(1): 25-28.

17. Joshi GP. Multimodal analgesia techniques and postoperative rehabilitation. Anesthesiol Clin North America. 2005;23(1):185-202. Doi: 10.1016/j.atc.2004.11.010.

18. Crosbie EJ, Massiah NS, Achiampong JY, Dolling $\mathrm{S}$, Slade RJ. The surgical rectus sheath block for post-operative analgesia: a modern approach to an established technique. Eur J Obstet Gynecol Reprod Biol. 2012; 160(2):196-200. Doi: 10.1016/j. ejogrb.2011.10.015.
19. Wada M, Kitayama M, Hashimoto H, Kudo T, Kudo M, and Takada N, et al. Brief reports: plasma ropivacaine concentrations after ultrasound-guided rectus sheath block in patients undergoing lower abdominal surgery. Anesth Analg. 2012; 114(1):230-2. Doi: 10.1213/ ANE.0b013e3182367a68.

20. Mukesh Kumar Shah, Sandeep S Kulkarni, Wendy Fun. The analgesic efficacy of ultrasound-guided modified rectus sheath block compared with wound infiltration in reduction of postoperative morphine consumption in women undergoing open hysterectomy or myomectomy: A randomized controlled trial 14/09/2012 trial. Journal of Obstetric Anesthesia and Critical Care

21. Smith BE, Suchak M, Siggins D, Challands J. Rectus sheath block for diagnostic laparoscopy. Anaesth 1988; 43: 947-8.

22. Muir J, Ferguson S. The rectus sheath block - well worth remembering. Anaesth 1996; 51: 893-4.

23. Azemati S, Khosravi MB. An assessment of the value of rectus sheath block for postlaparoscopic pain in gynecologic surgery. J Minim Invasive Gynecol 2005; 12: 12-5.

24. Gurnaney HG, Maxwell LG, Kraemer FW, Goebel T, Nance ML, Ganesh A. Prospective randomized observer-blinded study comparing the analgesic efficacy of ultrasound-guided rectus sheath block and local anaesthetic infiltration for umbilical hernia repair. Br J Anaesth 2011; 107: 790-5.

25. AR Godden, MJ Marshall, AS Grice, and IR Daniels. Ultrasonography guided rectus sheath catheters versus epidural analgesia for open colorectal cancer surgery in a single centre. Ann R Coll Surg Engl. 2013 Nov; 95(8): 591-594. 


\title{
Резиме
}

\section{ЕФЕКТОТ НА „БЛОКОТ НА ОБВИВКАТА НА МУСКУЛОТ РЕКТУС-АБДОМИНИС“ КАКО ДОДАТОК НА ОПШТА АНЕСТЕЗИЈА ВРЗ ПОСТОПЕРАТИВНАТА АНАЛГЕЗИЈА КАЈ ВОЗРАСНИ ПАЦИЕНТИ ПОДЛОЖЕНИ НА УМБИЛИКАЛНА ХЕРНИОПЛАСТИКА}

\author{
Андријан Карталов ${ }^{1}$, Никола Јанкуловски ${ }^{3}$, Билјана Кузмановска ${ }^{1}$, Милка Здравковска ${ }^{2}$ \\ Мирјана Шошолчева ${ }^{5}$, Марија Толевска ${ }^{1}$, Филип Наумовски ${ }^{1}$, Марија Срцева ${ }^{1}$, \\ Александра Пановска Петрушева ${ }^{1}$, Решеп Селмани ${ }^{3}$, Атанас Сивевски $^{4}$

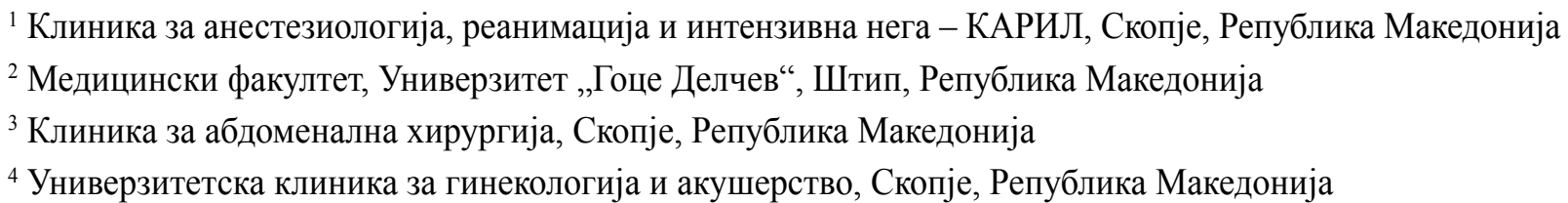

При умбиликална херниопластика, со помош на ултразвучно изведениот „блок на обвивката на мускулот ректус абдоминис“, настанува блокада на предните гранки на тораколумбарните нерви (Th7-Th12) со инјектирање на локален анестетик во просторот помеѓу мускулус ректус абдоминис и неговата задна обвивка. Целта на оваа рандомизирана двојно слепа студија беше да се оцени аналгетскиот ефект на билатералниот ултразвучно воден „блок на обвивката на мускулот ректус абдоминис“, како додаток на општата анестезија кај пациентите што се подложени на операција на умбиликална хернија.

Методи: Во оваа студија беа вклучени 60 (ASA I-II) возрасни пациенти за умбиликална херниопластика. Групата I ( $\mathrm{n}=30)$ - пациенти кај кои беше применета само општата анестезија. Групата II $(\mathrm{n}=30)$ - пациенти кај кои по индукција во општа анестезија се изведе билатерален ултразвучно воден „блок на обвивката на мускулот ректус абдоминис“ со $40 \mathrm{ml}$ 0,25\% бупивацаин. Во оваа студија ние ги проценивме демографските и клиничките карактеристики, степенот на болката - VAS при одмор на 2, 4, 6, 12 и 24 часа по оперативната интервенција и вкупната потрошувачка на морфиум во текот на првите 24 часа.

Резултати: Постојат статистички значајни разлики во однос на вредностите на VAS скалата меѓу групата I и групата II во сите постоперативни временски точки - 2 часа, 4 часа, 6 часа, 12 часа и 24 часа $(\mathrm{P}<0,00001)$. Кумулативната потрошувачка на морфиум за 24 часа по операцијата беше значително пониска во групата II (средна вредност $=3,73 \pm 1,41$ ) во однос на групата I (средна вредност $=8,76 \pm 2,41)$. Оваа разлика е статистички значајна $(\mathrm{p}=0,00076)$.

Заклучок: Ултразвучно водениот „блок на обвивката на мускулот ректус абдоминис“, кој се користи при умбиликална херниопластика, може да ја редуцира постоперативната болка и потребите за морфиум во текот на првиот постоперативен ден .

Клучни зборови: Умбиликална херниопластика, Ултразвучно воден „блок на обвивката на мускулот ректус-абдоминис“, Бупивакаин 